\title{
CITRIC ACID, LACTIC ACID AND OXYGEN METABOLISM OF FROZEN-THAWED SEMEN FROM FOUR SUBHUMAN PRIMATE SPECIES
}

\author{
D. R. ACKERMAN AND J. D. ROUSSEL \\ Laboratory of Physical Anthropology, Department of Anthropology, University of \\ California, Los Angeles, California 90024, and College of Agriculture, Department of \\ Dairy Science, Louisiana State University, Baton Rouge, Louisiana, U.S.A.
}

(Received 21st September 1970, revised 6th Fuly 1971)

A series of recent studies has been devoted to the systematic examination of characteristics of the semen of subhuman primates, with particular reference to the successful freeze-preservation of these specimens. Roussel \& Austin (1967a) showed that trypsin will liquefy the coagulum which appears in these ejaculates without harm to the motility of the sperm cells and the survival rates of cells from five species after 3 days' storage in liquid nitrogen have also been reported (Roussel \& Austin, 1967b). The initial content of fructose, lactic acid and citric acid in the frozen semen of animals from eleven species was studied (Ackerman \& Roussel, 1968) in order to establish the extent of variability among species in these aspects of sperm physiology. Metabolic behaviour of the frozen-preserved spermatozoa of $M$. mulatta, M. irus, E. patas and $C$. aethiops are reported here.

Specimens were obtained from animals located at the Delta Regional Primate Research Center, Covington, Louisiana. Collections were made by means of electroejaculation (Weisbroth \& Young, 1965); dilution and freezing procedures have been described (Roussel \& Austin, 1967b). Thirty-seven specimens were collected, and these were stored in liquid nitrogen for 6 to 12 months. The whole semen was assayed for the concentration of citric acid (Saffran \& Denstedt, 1948) and lactic acid (Barker \& Summerson, 1941), before and after a 3 -hr incubation at $35^{\circ} \mathrm{C}$, in air or in $100 \%$ nitrogen. The respiration of some specimens was followed for $2 \mathrm{hr}$ at $35^{\circ} \mathrm{G}$ with a polarographic oxygen sensor (Yellow Springs Instrument Co., Yellow Springs, Ohio). Sperm-free seminal plasma containing $7 \cdot 5 \% \mathrm{v} / \mathrm{v}$ glycerol was employed as a control for these measurements. Absolute values for $\mathrm{O}_{2}$ consumed were determined on the basis $\alpha=0.0245$.

Table 1 describes the count, motility and eosin-staining characteristics of the semen specimens immediately upon thawing at room temperature and after incubation. Table 2 expresses the metabolic performance of the specimens. The post-thaw motility of all specimens was very low after 6 to 12 months' storage. In no instance was the rate of recovery as high as the rates reported after 3 days' storage for specimens of some of the same animals (Roussel \& Austin, 1967b). There were no differences between species in this respect, 
long periods of storage in liquid nitrogen being more deleterious than shorter ones (Salisbury \& Hart, 1970). The metabolism of citric acid and of lactic acid appeared to be uniform for the species examined here, and similar to that of mammalian semen generally. Where $\mathrm{Zo}_{2}$ values could be obtained, they were similar for frozen preserved rhesus monkey spermatozoa to those reported

TABLE 1

CHARAGTERISTICS OF SEMEN SPECIMENS FROM FOUR SUBHUMAN PRIMATE SPECIES

\begin{tabular}{|c|c|c|c|c|c|c|c|}
\hline Species & $\begin{array}{l}\text { No. of } \\
\text { animals }\end{array}$ & $\begin{array}{l}\text { No. of } \\
\text { speci- } \\
\text { mens }\end{array}$ & $\begin{array}{l}\text { Months } \\
\text { stored at } \\
-196^{\circ} C\end{array}$ & $\begin{array}{c}\text { Count } \\
\times 106 / \mathrm{ml}\end{array}$ & $\begin{array}{c}\% \text { motile } \\
\text { pre- } \\
\text { incubation }\end{array}$ & $\begin{array}{c}\% \text { motile } \\
\text { post }- \\
\text { incubation }\end{array}$ & $\begin{array}{c}\% \text { eosin } \\
\text { negative } \\
\text { post- } \\
\text { incubation }\end{array}$ \\
\hline M. mulatta & 5 & 15 & $6.2 \pm 0.52$ & $831 \cdot 9 \pm 229 \cdot 7$ & $2 \cdot 6 \pm 1 \cdot 1$ & $1 \cdot 1 \pm 0 \cdot 5$ & $3 \cdot 4 \pm 1 \cdot 7$ \\
\hline$M$. irus & 3 & 10 & $7.2 \pm 0.76$ & $1317 \cdot 5 \pm 284 \cdot 8$ & $8 \cdot 2 \pm 2 \cdot 7$ & $1.7 \pm 0.9$ & $10 \cdot 8 \pm 4 \cdot 1$ \\
\hline$E$. patas & 3 & 5 & $4.9 \pm 0.57$ & $655 \cdot 8 \pm 261 \cdot 2$ & $3.0 \pm 0.9$ & $1.0 \pm 0.9$ & $7 \cdot 2 \pm 2 \cdot 6$ \\
\hline C. aethiops & 2 & 7 & $7 \cdot 36 \pm 1 \cdot 11$ & $1428 \cdot 1 \pm 818 \cdot 1$ & $1 \cdot 1 \pm 0.8$ & $0.4 \pm 0.3$ & $6 \cdot 3 \pm 2 \cdot 1$ \\
\hline
\end{tabular}

Results expressed as Means \pm S.E.

TABLE 2

CITRIG ACID AND LACTIC ACID METABOLISM OF THIRTY-SEVEN PRIMATE EJAGULATES, AND $\mathrm{O}_{2}$ CONSUMPTION OF EIGHT EJAGULATES

\begin{tabular}{|c|c|c|c|c|c|c|}
\hline Species & $\begin{array}{l}\text { No. of } \\
\text { animals }\end{array}$ & $\begin{array}{c}\text { No. of } \\
\text { specimens }\end{array}$ & $\begin{array}{c}\text { Gas } \\
\text { phase }\end{array}$ & $\begin{array}{c}\text { Citric acid } \\
\left(m g / 10^{8} \text { cells } / 3 \mathrm{hr}\right)\end{array}$ & $\begin{array}{c}\text { Lactic acid } \\
\left(m g / 10^{8} \text { cells } / 3 h r\right)\end{array}$ & $\mathrm{O}_{2} \underset{\left(\mu l / 10^{8} \text { cells } / \mathrm{hr}\right)}{\text { consumption }}\left(\mathrm{ZO}_{2}\right)$ \\
\hline M. mulatta & 5 & $\begin{array}{r}11 \\
4\end{array}$ & $\begin{array}{l}\text { Air } \\
\mathrm{N}_{2}\end{array}$ & $\begin{array}{l}-5 \cdot 52 \pm 10 \cdot 57 \\
-24 \cdot 65 \pm 32 \cdot 19\end{array}$ & $\begin{array}{r}-0.99 \pm 1.52 \\
2.40 \pm 1.93\end{array}$ & $14 \cdot 72 \pm 12 \cdot 03(\mathrm{~N}=3)$ \\
\hline M. irus & 3 & $\begin{array}{l}6 \\
4\end{array}$ & $\underset{N_{2}}{\mathrm{Air}}$ & $\begin{array}{l}2 \cdot 69 \pm 3.04 \\
0.73 \pm 0.68\end{array}$ & $\begin{array}{l}-1.22 \pm 0.31 \\
-1.51 \pm 1.78\end{array}$ & $10 \cdot 52 \pm 2 \cdot 45(\mathrm{~N}=3)$ \\
\hline E. patas & 3 & $\begin{array}{l}4 \\
1\end{array}$ & $\underset{\mathrm{N}_{2}}{\mathrm{Air}}$ & $\begin{array}{r}-15 \cdot 69 \pm 7 \cdot 59 \\
3 \cdot 06\end{array}$ & $\begin{aligned} & 3.48 \\
-0.95 & \pm 2 \cdot 88\end{aligned}$ & $0(\mathrm{~N}=1)$ \\
\hline C. aethiops & 2 & $\begin{array}{l}5 \\
2\end{array}$ & $\underset{N_{2}}{\operatorname{Air}}$ & $\begin{array}{c}0.07 \pm 1 \cdot 14 \\
50 \cdot 57 \pm 35 \cdot 20\end{array}$ & $\begin{array}{l}0.13 \pm 1 \cdot 21 \\
1.06 \pm 2.44\end{array}$ & $0(\mathrm{~N}=1)$ \\
\hline
\end{tabular}

for untreated rhesus spermatozoa by Hoskins \& Patterson (1968), despite the low motility of the former cells.

This work was supported by Grant No. HD 02592.

\section{REFERENGES}

Ackerman, D. R. \& Roussel, J. D. (1968) Fructose, lactic acid and citric acid content of the semen of eleven subhuman primate species and of man. F. Reprod. Fert. 17, 563.

Barker, S. B. \& Summerson, W. H. (1941) The colorimetric determination of lactic acid in biological material. 7. biol. Chem. 138, 535.

Hoskins, D. D. \& Patterson, D. L. (1968) Metabolism of rhesus monkey spermatozoa. F. Reprod. Fert. 16, 183.

Rousser, J. D. \& Austin, G. R. (1967a) Enzymic liquefaction of primate semen. Int. F. Fert. 12, 288.

Rousser, J. D. \& Austin, C. R. (1967b) Preservation of primate spermatozoa by freezing. F. Reprod. Fert. 13, 333. 
Saffran, M. \& Denstedt, O. F. (1948) A rapid method for the determination of citric acid. F. biol. Chem. 175, 849 .

Salisbury, G. W. \& Hart, R. G. (1970) Gamete ageing and its consequences. Biol. Reprod. Suppl. 2, 1. Weisbroth, S. \& Young, F. A. (1965) The collection of primate semen by electro-ejaculation. Fert. Steril. 16, 229. 